\title{
Remittance and Economic Growth Nexus in Nigeria: Does Financial Sector Development Play a Critical Role?
}

\author{
${ }^{*}$ Friday Osemenshan Anetor \\ Pinl-Itlintic Lniversity, Ligaso, ligeriia
}

\begin{abstract}
The purpose of the study was to examine the relationship between remittances, financial sector development, and economic growth in Nigeria over the period 1981 to 2017. The study used the autoregressive distributed lag (ARDL) model to analyze the longrun and short-run relationships between the variables. The outcome of the study revealed that the variables are bound together in the long-run. The results also showed that remittances have a negative and significant effect on economic growth both in the long-run and short-run. The study also established that financial sector development has a negative and significant impact on economic growth both in the long-run and short-run. Further, the study confirmed the existence of complementarity between remittances and financial sector development in influencing economic growth. In addition, study revealed that inflation has a negative and significant effect on economic growth both in the long-run and short-run. The findings of the study showed that trade openness, government expenditure, and population growth have no significant impact on economic growth both in the long-run and short-run.

Keywords: Remittances, financial development, economic growth, $A R D L$, Nigeria

JEL:F24, F43, O16
\end{abstract}

In recent time, remittances have constituted one of the largest sources of foreign capital inflows to the developing economies as they account for about 27 percent of the gross domestic product (GDP) (Aggarwal, Demirgüç-Kunt and Peria, 2011; Giuliano and Ruiz-Arranz, 2009; Meyer and Shera, 2017; Rao and Hassan, 2011; Sibindi, 2014). The dramatic increase in the volume of remittances to the developing nations can be attributed to the improved immigration between the developed countries and the developing countries and the technological advancement that has enhanced the international transfer of payment between individuals at a low cost (Meyer and Shera, 2017). According to the World Bank, remittances are personal transfers or compensation of workers. Anton (2010), Woodruff (2007), Woodruff and Zenteno (2007), and Yang (2008) noted that remittances constitute an important source of savings and capital for investment in health, education, and entrepreneurship thereby enhancing productivity and employment, which culminate into economic growth. Remittances can also help in enhancing the growth of the financial sector on the notion that some of the remittances are converted and deposited with banks thus making the funds available for lending to the private sector and this, in turn, facilitate economic growth (Aggarwal et al., 2011; Misati and Nyamon- 


\section{Anetor}

go, 2011). Remittances provide support for the welfare of the relatives left behind thus contributing to the eradication of poverty in the recipient country (Adams and Page, 2005; Gupta, Pattillo and Wagh, 2009).

Despite the enormous benefits of remittances on the performance of developing countries, the impact of remittances on economic growth is still ambiguous (Kumar et al., 2018). Some literature noted that remittances exert a positive influence on economic growth (Catrinescu et al., 2009; Jawaid and Raza, 2012; Kumar et al., 2018; Meyer and Shera, 2017; Nyamongo et al., 2012; Pradhan, Upadhyay and Upadhyaya, 2008), other strands of literature emphasized on a negative or zero relationship between remittances and growth (Barajas et al., 2009; Chami, Fullenkamp and Jahjah, 2005; Feeny, lamsiraroj and McGillivray, 2014; Lim and Simmons, 2015). The inconclusive debate on the relationship between remittances and economic growth notwithstanding, the literature is more concerned whether the financial development plays a critical role in the remittances led growth relationship (Abida and Sghaier, 2014; Chowdhury, 2016; Kumar et al., 2018, Raheem, 2015; Sibindi, 2014). It is argued that a well-developed and functioning financial sector is fundamental for economic growth (Bagehot, 1873; Cameron, 1967; Goldsmith, 1969; McKinnon, 1973; Schumpeter, 1912; Shaw, 1973) because it helps to produce essential information for investments, enhance efficient allocation and utilization of savings, monitor investments, improve trading and diversification, and manage risk (Levine, 2005). Adenutsi (2011), Calderón and Liu (2003), Demetriades and Hussein (1996), Durusu-Ciftci, Ispir and Yetkiner (2017), Gregorio and Guidotti (1995), Valickova, Havranek, and Horvath (2015), therefore, stressed that the financial sector provides an avenue whereby funds, such as remittances, can be mobilized into productive investment that will culminate into economic growth.

Besides the argument portrayed by the empirical literature, some theories have also explained the link between remittances and economic growth. For example, the pure selfinterest theory and the pure altruism theory, developed by Lucas and Stark (1985) and Stark (1991), attempt to provide a lucid explanation on the relationship between remittances and economic growth. The self-interest theory noted that migrants save at his destination and remit money to their country to embark on investment projects that could culminate into growth. The pure altruism theory, on the other hand, opined that remitters send money to their families due to the emotional ties. The money sent increases the income and purchasing power of their family members thereby resulting in the growth of the economy. 
In light of the above argument, this study examines the remittances led growth relationship as well as the role of the financial sector development in the Nigerian economy. The study focuses on Nigeria because it is one of the top recipients of remittances in the World (Ratha et al., 2016) and remittances have been making a significant contribution to the country's GDP over the past three decades (Figure 1).

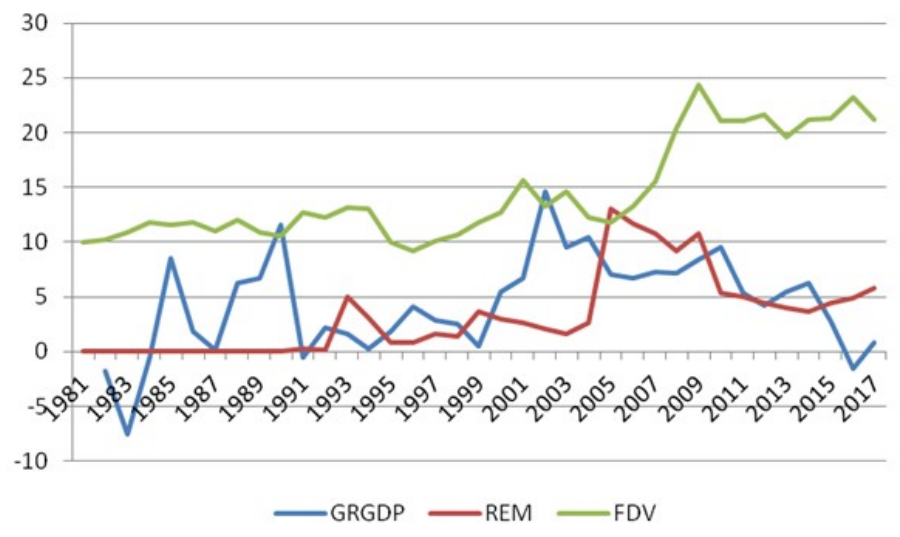

Source: Source: Data used from CBN Statistical Bulletin (2017) and WDI (2017)

Figure 1. Overview of Remittances, Financial Development and Growth

Though, the literature on remittances and economic growth in Nigeria is not new (e.g., Adarkwa, 2015; Akinpelu et al., 2013; Audu, 2012; Danmola and Wakili, 2013; Oluwafemi and Ayandibu, 2014; Oshota and Badejo, 2015); however, extant literature on the role of financial sector development in remittances-growth nexus is sparse. It is believed that the outcome of this study will unravel the intricate relationship between remittances, financial sector development, and economic growth thus; chatting the way forward for policymakers in Nigeria and other parts of the World.

The remaining parts of the study are structured as follows: Section 2 is the theoretical review. Section 3 presents a review of the empirical literature on remittance-finance-growth nexus. Section 4 describes the methodology and data employed for the study. Section 5 presents the empirical results. Section 6 discusses the findings. Section 7 is the conclusion and the implications of the study. The last section offers the limitation and direction of future research.

\section{LITERATURE REVIEW}

Even though numerous literatures on remittances and its importance on the growth of developing countries exist, there is still a paucity of a well-developed systematic theory of remittances. Notwithstanding, Lucas and Stark (1985) and Stark (1991) have developed notable theories of 


\section{Anetor}

remittance, and these include the pure self-interest theory and the pure altruism theory. The pure selfinterest theory posits that migrant saves at his destination and remit money to his country of origin in a bid to embark on investment projects such as the purchase of land and property, and invest in the stock market or the money market. These investments, which are administered by the migrant's relatives in their home country, help to increase the overall level of investment in the home country and this will culminate into higher economic growth. De la Brière et al. (1997), Hoddinott (1994), Osili (2004), and Schrieder and Knerr (2000) noted that the more the quest for asset acquisition by migrants, more the amount of remittances sent. As remittances are channeled into investment purpose, through the financial institution, the more the domestic economy experiences higher economic growth. The pure altruism theory, on the other hand, stressed that migrants send remittances to their family members in the country of origin because they care about them. The pure altruism theory further asserts that the reasons behind the altruistic behavior are of the emotional and social kind and are aimed at enhancing the standard of living of their family and at preserving and strengthening the ties between remitters and their relatives at home (Ambrosetti, Cela and Fokkema, 2011). The theory, therefore, noted a positive relationship between the amount of remittances and migrant's income and an inverse relationship with the income of the household in the country of origin (Durand et al., 1996; Lucas and Stark, 1985; Osili, 2004).

Besides the theories of Lucas and Stark (1985) and Stark (1991), Elbadawi, Rocha and Mundial (1992) conceived the causes of remittances from two major strands: the endogenous migration approach and the portfolio approach. The endogenous approach centers on the economy of the family, and it is closely related to the pure self altruism theory. The endogenous migration approach noted that the determinants of remittances also include economic data, which describe the economic circumstances faced by the migrant and his family as well as the demographic data that describe the strength of family ties or the existence of other family arrangements. The portfolio approach, on the other hand, does not involve issues of family ties. According to the portfolio view, the migrants earn income and decide how to allocate savings between the host country assets and home country assets. The portfolio approach noted that factors such as rate of returns on assets, interest rate differentials, the return on real estate in the home country and inflation rate influence the decision to remit. As a result, the portfolio approach sees remittances as other capital inflows, and they are expected to have a positive impact on growth.

The role of remittances on economic growth has been discussed in the literature. However, empirical studies have stressed the role of financial development in the remittances-growth nexus. Rao and Hassan (2011) lend credence to this assertion by emphasizing that remittances could have an indirect effect on economic growth through investment and financial sector development. Whether remittances exert influence on economic growth through the development of the financial sector rema- 
ins unclear in the literature (Chowdhury, 2016).

Using the system generalized method of moments (SGMM) regression, Giuliano and Ruiz-Arranz (2009) studied the link between remittances, financial development and economic growth in 100 developing countries. The result showed that remittances exert a positive and significant influence on economic growth in nations where the financial sector is less developed by providing an alternate means to funding investment and assisting in overcoming liquidity challenges. Contrary to the study by Giuliano and Ruiz-Arranz (2009), Bettin and Zazzaro (2012) employed OLS and SGMM methods of estimation to analyze the growth effect of remittances and financial development in 66 developing countries between 1970 and 2005. The outcome of the study revealed that remittances and bank efficiency have a complementarity effect on economic growth. This implies that remittances only facilitate economic growth in countries with a well-functioning bank and does not promote growth in countries with bank inefficiency.

Sibindi (2014) investigated the tripartite relationship between the remittances, financial sector development and economic growth in Lesotho between the period 1975-2010 applying the vector error correction model (VECM) and Granger causality. The study noted a one-directional causality running from remittances to economic growth. The outcome of the study also lends credence to the supplyleading growth hypothesis by noting a unidirectional causality of financial development on growth.

Nyamongo et al. (2012) in their tripartite study of remittances, financial development, and economic growth in 36 countries between 1980 and 2009 used panel econometric framework and noted that remittances exert a significant and positive effect on economic growth; however, the study found that the economic growth effect of financial development is weak, that is the development of the financial system has not culminated into economic growth in those countries studied. In analyzing the link between financial development and economic growth Mundaca (2009) employed a dataset of 39 Latin American and Caribbean nations between the period 1970 and 2002, and found that there exists a complementarity between remittances and financial development in facilitating economic growth.

Chowdhury (2016) used a dynamic panel estimation to investigate the link between financial development, remittances, and growth in 33 developing countries ranked as the top remittance recipients between the period 1979 and 2011. The study noted that while remittances exert a positive influence on growth, the role of financial sector development is insignificant in influencing the remittance-growth nexus. The study concluded that more developed financial systems might woo more remittances; however, the interaction effect of financial development and remittances does not enhance growth.

Meyer and Shera (2017) examined the economic growth effect of remittances in six (6) countries, 


\section{Anetor}

Bulgaria, Albania, Moldova, Macedonia, Romania, and Bosnia Herzegovina between the period 1999 and 2013 and noted that remittances exert a positive effect on economic growth. Based on the theoretical review and the literature review, the following hypotheses are proposed:

$\mathrm{H}_{01}$ : Remittances do not have a significant effect on economic growth.

$\mathrm{H}_{02}$ : Financial sector development does not have a significant influence on economic growth.

$\mathrm{H}_{03}$ : The interaction of remittances with financial sector development does not have a significant effect on economic growth.

\section{METHODOLOGY}

\section{-Data Source}

The study used annual time series data between the period 1981 and 2017. Annual data on economic growth, which was measured as the growth rate in the gross domestic product (GRGDP), were obtained from the Central Bank of Nigeria (CBN) statistical bulletin. Data on remittances as a percentage of GDP (REM) were derived from the World Bank Development Indicators (WDI). Financial development (FDV) was measured as M2 (money supply, which includes M1- narrow money, plus short-term deposits in banks) as a ratio of GDP (Rao and Hassan, 2011) and data on this variable were obtained from CBN statistical bulletin. Data on trade openness (TOP), which was measured as the percentage ratio of the sum of exports and imports to GDP, were sourced from the CBN statistical bulletin. The annual growth rate in population (POP) was obtained from the World Development Indicator (WDI). Data on government's expenditure as a percentage of GDP (GXP) were extracted from the CBN statistical bulletin while data on gross capital formation as a percentage of GDP (GCF) were sourced from the WDI.

\section{-Model}

Based on the literature review, the theoretical relationship of remittances, and financial sector development with economic growth is estimates in the following equation:

$$
G R G D P=\beta_{3}+\beta_{1} R E M+\beta_{2} F D V+\beta_{3}(R e m F d v)+\mu
$$

Where GRGDP is the growth rate in GDP, REM is remittances as a percentage of GDP, $F D V$ is financial development measured as M2 as a ratio of GDP, RemFdv represents the interaction effects of remittances and financial development on growth. A positive (negative) and significant interaction term will indicate the complementarity (substitutability) of remittances and financial development in 
economic growth (Chowdhury, 2016; Giuliano and Ruiz-Arranz, 2009). $\boldsymbol{\mu}$ is the stochastic term.

The literature has shown that control variables also influence the level of economic growth. These variables include inflation, trade openness, population growth, government expenditure and domestic investment (Adenola and Saibu, 2017; Agbonkhese and Asekome, 2014; Choe, 2003; Keho, 2017 , Š vigir and Milo š, 2017). Hence, equation (1) can be modified to incorporate the control variables as:

$$
\begin{aligned}
G R G D P=\lambda_{0} & +\lambda_{1} R E M+\lambda_{2} F D V+\lambda_{3}(R e m F d v)+\lambda_{4} I N F+\lambda_{5} T O P+\lambda_{6} P O P+\lambda_{7} G X P \\
& +\lambda_{8} G C F+\varepsilon
\end{aligned}
$$

Where $I N F$ is inflation, $T O P$ is trade openness measured as the percentage ratio of the sum of exports and imports to GDP, POP is annual growth rate on population, GXP is government expenditure as the percentage of GDP, $G C F$ is gross capital formation as a percentage of GDP. $\varepsilon$ is the error term.

\section{-Unit Root Tests}

To test the stationarity of the variables, the study employed the Augmented Dickey-Fuller (ADF) and the Phillip-Peron test. The ADF test of stationarity is used for this study because it is considered as the simplest approach to test stationarity of time series data and it is also appropriate for a large and complex set of data (Anetor, 2016). The ADF test estimation procedure is expressed as follows:

$$
\Delta Y_{t}=\lambda+\delta t+\beta Y_{t-1}+\varphi_{i} \sum_{i=n}^{n} \Delta Y_{t-1}+\mu_{t}
$$

Where $\Delta Y_{t}$ connotes the lag difference of the variable of interest, $\lambda$ is the constant term, $n$ is the number of lag, $t$ is the time trend, and $\mu_{t}$ is the error term. The study also employed the PhillipsPerron test to test for stationarity as it is commonly used as an alternative to the ADF test (Fedorová, 2016).

\section{-Autoregressive Distributed Lag (ADRL) Model}

This study used the ARDL approach to examine the link between remittances, financial development, and economic growth. ARDL was employed because it allows for the combination of variable integrated of the order of $I(0)$ and I(1) (Belloumi, 2014). It also provides estimates of the corresponding error correction model (Ogbechie and Anetor, 2016). The ARDL model used in the study can be expressed as: 


\section{Anetor}

$$
\begin{aligned}
\Delta G R G D P_{t}= & \beta_{0} \\
+ & \omega_{1} G R G D P_{t-i}+\omega_{2} R E M_{t-i}+\omega_{3} F D V_{t-i}+\omega_{4}(\operatorname{RemFdv})_{t-i}+\omega_{5} I N F_{t-i} \\
& +\omega_{6} T^{n} P_{t-i}+\omega_{7} P O P_{t-i}+\omega_{8} G X P_{t-i}+\omega_{9} G C F_{t-i}+\sum_{i=1}^{n} \beta_{i} \Delta G R G D P_{t-i} \\
& +\sum_{i=1}^{n} \alpha_{i} \Delta R E M_{t-i}+\sum_{i=1}^{n} \delta_{i} \Delta F D V_{t-i}+\sum_{i=1}^{n} \theta_{i} \Delta(R e m F d v)_{t-i}+\sum_{i=1}^{n} \varphi_{i} \Delta I N F_{t-i} \\
& +\sum_{i=1}^{n} \emptyset_{i} \Delta T O P_{t-i}+\sum_{i=1}^{n} \lambda_{i} \Delta P O P_{t-i}+\sum_{i=1}^{n} \gamma_{i} \Delta G X P_{t-i} \\
& +\sum_{i=1}^{n} \eta_{i} \Delta G C F_{t-i}+\mu_{t}
\end{aligned}
$$

Where $\beta_{v}$ is a drift component, $\Delta$ represents the first difference of the variables, $n$ is the lag lengths and the $\mu_{t}$ is error term. The coefficient of the lagged variables $\left(\omega_{1}\right.$ to $\left.\omega_{9}\right)$ are the long-run multipliers while $\alpha_{i}, \delta_{i}, \theta_{i}, \varphi_{i}, \varphi_{i}, \lambda_{i}, \gamma_{i}$, and $\eta_{i}$ represent the short-run impact on economic growth.

\section{RESULTS}

Table 1 (see Appendix-I) presents the summary statistics of the variables of interest. The mean of the variables varies from 2.27 for population to 19.56 for inflation. The statistics indicate that the average annual growth rate of Nigeria is 4.45 and the average contribution of remittances to the GDP of the nation is 3.32 while the average level of development of the financial sector is 14.47 . The inflation rate on the average is 19.56, which is considerably high. In terms of variability, as indicated by the standard deviation, the result shows that inflation has the highest degree of variability while the population shows the least level of variability.

\section{-Unit Root Test}

Table 2 (see Appendix-II) shows the outcome of the Augmented Dickey-Fuller (ADF) and the PhillipPeron (PP) unit root tests. The results indicate that variables are stationary at level and first difference; hence, the ARDL method of estimation becomes more appropriate for the estimation of the long-run and short-run relationship between remittances, financial development, and economic growth.

\section{-ADRL Bounds Test for Cointegration}

Table 3 indicates the outcome of the ARDL bound test. The essence of the test is to determine whether there is an existence of a long-run relationship between the variables. The result of the test indicates that the $f$-Statistic is equal to 4.385 and it is larger than the upper bound (3.79) critical values at 1 percent, 5 percent, and 10 percent significance level. Hence, the null hypothesis (i.e. $H_{0}: \omega_{1}=\omega_{2}=\omega_{3}=\omega_{4}=\omega_{5}=\omega_{5}=\omega_{7}=\omega_{8}=\omega_{9}=0$ ) of no cointegration is rejected 
while the alternate hypothesis (i. c. $H_{1}: \omega_{1} \neq \omega_{2} \neq \omega_{3} \neq \omega_{4} \neq \omega_{5} \neq \omega_{6} \neq \omega_{7} \neq \omega_{8} \neq \omega_{9} \neq 0$ ) of the presence of cointegration cannot be rejected. This suggests that a long-run relationship exists between the variables of interest.

\begin{tabular}{lllll}
\hline $\mathbf{K}$ & $\boldsymbol{f}$ - & Critical Value & $\begin{array}{c}\text { Lower Bound } \\
\text { Value }\end{array}$ & $\begin{array}{c}\text { Upper Bound } \\
\text { Value }\end{array}$ \\
& Statistics & & 2.79 & 4.1 \\
8 & \multirow{3}{*}{4.385} & $5 \%$ & 2.22 & 3.39 \\
& & $10 \%$ & 1.95 & 3.06 \\
\hline
\end{tabular}

Table 3. ARDL Bound Test

Table 4 (see Appendix-III) shows the results of the long-run estimates. The results show that there is a negative relationship between remittances (REM) and economic growth in the long-run and it is significant. As a result, the null hypothesis $\left(\mathrm{H}_{01}\right)$, which states that remittances do not have a significant effect on economic growth, is rejected. The study also found that financial sector development $(F D V)$ has a negative and significant impact on economic growth; hence, the null hypothesis $\left(\mathrm{H}_{02}\right)$ that states that financial sector development does not have a significant effect on economic growth is rejected. Further, the result showed that the interaction effect of remittances and financial sector development ( $R e m F d v$ ) on economic growth is positive and statistically significant. This indicates that remittances and financial sector development are complementary and not substitutes. Hence, the null hypothesis $\left(\mathrm{H}_{03}\right)$, which states that the interaction of remittances and financial sector development does not have a significant effect on economic growth, is rejected. This result lends credence to previous studies by Bettin and Zazzaro (2012) and Mundaca (2009).

Inflation (INF) exhibits a negative relationship with economic growth in the long-run and is significant. Considering the impact of trade openness (TOP) on economic growth, the relationship is positive but statistically insignificant. This connotes that the degree of openness does not stimulate economic growth. Population growth $(P O P)$ in relation to economic growth is negative but insignificant. Government expenditure (GXP) does not exert any influence on economic growth. This is due to the fact that government expenditure is skewed to recurrent expenditure as against capital expenditure that can stimulate growth. The relationship between investment (GCF) and economic growth is negative and significant in the long-run. The reason why domestic investment has not resulted into economic growth is due to poor infrastructural facilities such as epileptic power supply; unfavorable 


\section{Anetor}

macroeconomic performance, e.g., high rate of inflation and interest rate; and the rising level of insecurity in the country.

Table 5 (see Appendix-IV) shows the short-run dynamic coefficient and the speed of adjustment. The result shows that the relationship between remittances ( $R E M)$ and economic growth is negative and is statistically significant in the short-run. Similarly, financial development (FDV) exerts a negative influence on economic growth in the short-run and is significant. The interaction term (RemFdv) has a positive and significant effect on economic growth indicating that remittance and financial development are both complementary in influencing the rate of economic growth. The result also shows that inflation (INF) has a negative and significant impact on economic growth in the short-run. Further, the result indicates that trade openness (TOP), population growth $(P O P)$, government expenditure (GXP) and investment (GCF) have no significant impact on economic growth.

The error correction term (ECT) explains how quickly or slowly in which the relationship is restored to its equilibrium path. The coefficient of the ECT is expected to be negative and must be statistically significant. A significant ECT proofs the existence of a stable long-run relationship. Table 5 indicates that the coefficient of the ECT is equal to -0.74 and it is significant. This suggests that deviation from the long-run path is corrected by 74 percent over the following year. The R-squared of 0.84 indicates that all the explanatory variables account for 84 percent changes or variation in economic growth. The f-statistic, which indicates the overall significance level of the estimate, showed that the overall estimate is significant as the $p$-value is less than 5 percent. The DW-statistic of 1.95 indicates the absence of first-order serial autocorrelation.

Table 6 depicts the diagnostic test result of the ARDL estimates of both the long-run and short-run. The purpose of the test is to determine whether the underlying ARDL Eq. (4) fits very well and the model is globally significant. The result indicates that the regression passes all diagnostic tests against serial correlation (Durbin Watson test and Breusch-Godfrey test), heteroske dasticity (Breusch-Pagan

\begin{tabular}{ccc}
\hline & $\chi^{2}$ Statistics & Probability \\
\hline Breusch-Godfrey Serial Correlation LM Test & 2.79 & 0.08 \\
Breusch-Pagan-Godfrey Heteroskedasticity Test & 0.64 & 0.78 \\
Jarque-Bera test & 1.43 & 0.48 \\
Ramsey RESET Test & 0.71 & 0.40 \\
\hline Source: Author's Computation using EViews 9 & &
\end{tabular}

Table 6. Diagnostic Test Results 
-Godfrey heteroskedasticity test), and normality of errors (Jarque-Bera test). The Ramsey RESET test also indicates that the model is well specified.

Figure 2 and 3 shows the cumulative sum (CUSUM) of recursive residuals and the CUSUM of the square (CUSUMSQ) tests respectively. The purpose of the test is to determine whether the long-run and the short-run dynamics estimates are stable. The results show that the coefficients are stable because the plots of the CUSUM and CUSUMSQ statistic fall inside the critical bands of the 5 percent confidence interval of parameter stability.

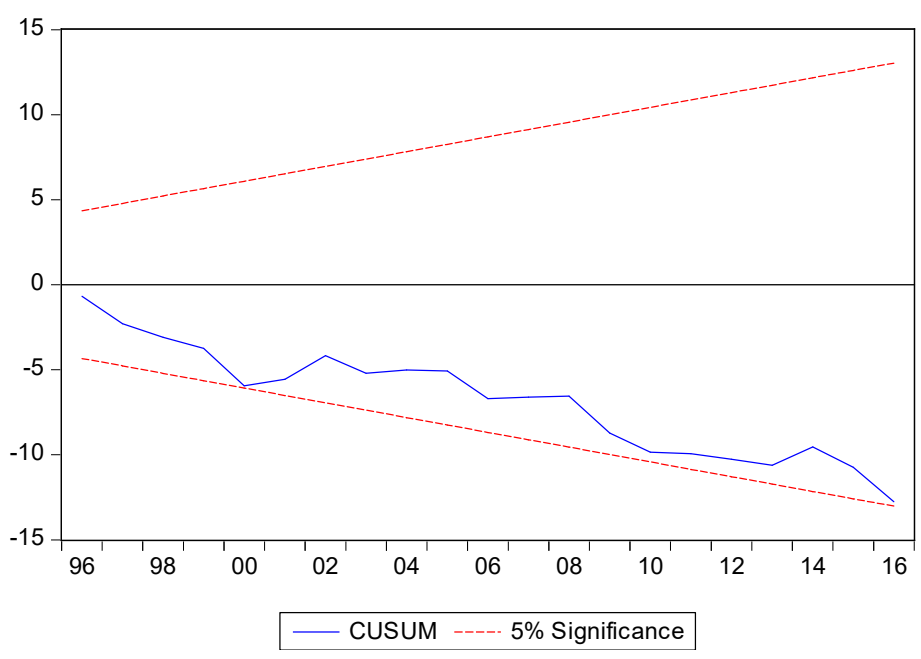

Source: Authors' Computation using EViews 9

Figure 2. Plot of CUSUM Test

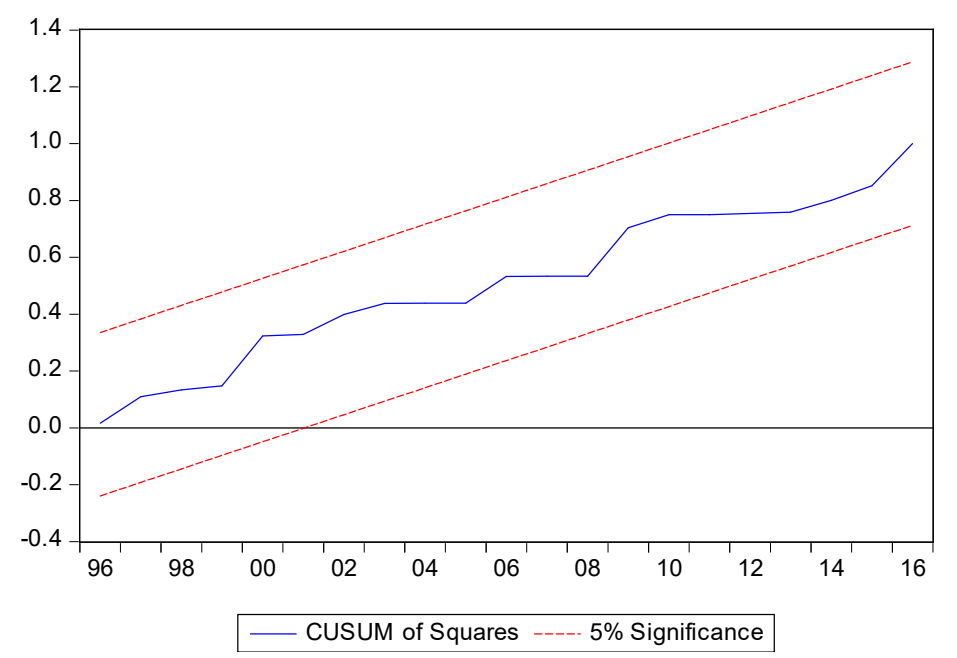

Source: Authors' Computation using EViews 9

Figure 3. Plot of CUSUMSQ Test 


\section{Anetor}

\section{DISCUSSION}

The study examined the relationship between remittances, financial sector development, and economic growth. The study also investigated whether financial sector development plays a complementarity or substitutability role in remittances-growth nexus. The study noted that remittances had a negative and significant effect on economic growth. This finding lends credence to extant studies (Chowdhury, 2016; Meyer and Shera, 2017; Rao and Hassan, 2011) that noted that remittances have a significant effect on economic growth. This is indicative that remittances are mostly spent on consumption rather than a productive investment that would contribute to long-run growth.

The outcome of the study has also revealed that financial sector development had a negative significant effect on economic growth both in the long-run and short-run. This outcome is contrary to the work of Schumpeter (1912) and McKinnon (1973), who stressed the important role of financial institutions on the growth of the economy. The economic rationale for this result is that a large proportion of the gross savings in the financial sector are not channeled to the real or productive sectors of the economy. The financial sector, particularly the banking system, would prefer to invest depositors' funds in short-term and less risky investment such as treasury bills, treasury certificate rather than to invest or provide loans to the real sector such as agriculture and manufacturing. The study also noted that the interaction of remittances and financial sector development on growth is positive and significant both in the long-run and short-run. This implies that remittances and financial sector development have a complementarity effect on growth; hence, an efficient financial system is a requirement for remittances to engender economic growth. This outcome supports the findings of Bettin and Zazzaro (2012), which noted that the interaction of remittances and financial development has a positive and significant impact on growth.

The study has shown that inflation has a negative and significant impact on economic growth. The economic explanation for this result is that inflation exerts an upward trend in the cost of production and producers tend to pass it on to consumers in the form of a high price. A high price of good reduces the effective demand for commodities and this, in turn, make producer to cut-down production. Inflation causes export goods less competitive abroad.

\section{CONCLUSION}

This study investigated the relationship between remittances and economic growth and its interaction with financial development in Nigeria between the period 1981 to 2017. Employing ARDL to determine the long-run and short-run relationship the study found that there is cointegration amongst the variables. The result showed that remittances do not promote economic growth both in the long-run 
International Journal of Management, Economics and Social Sciences

and short-run. This indicates that remittances are mostly spent on consumption and not on productive investment that would engender economic growth. Also, the outcome of the study established that financial development has a negative impact on economic growth both in the long-run and short-run. The rationale for this is that savings in the financial sector are not properly channeled to the real or productive sectors of the economy. The financial sector, particularly banking system in most cases channel depositors' funds in short-term and less risky investment such as treasury bills, treasury certificate rather than to invest or provide loans to the real sector such as agriculture and manufacturing. Further, the study found that the interaction of remittances and financial development are both complementary and not substitute in influencing economic growth. In addition, the study revealed that inflation has an adverse effect on economic growth both in the long-run and short-run. This is indicative that inflation culminates into an upward movement in the cost of production and producers tend to pass it on to consumers in the form of a high price. A high price of a good reduces the effective demand for commodities and this, in turn, make producer to cut-down production. The findings of the study also showed that trade openness, government expenditure, and population growth have no significant impact on economic growth both in the long-run and short-run. Finally, the result confirmed that domestic investment has not resulted into economic growth due to poor infrastructural facilities such as epileptic power supply, unfavorable macroeconomic performance, e.g., high rate of inflation and interest rate; and the rising level of insecurity in the country.

\section{IMPLICATIONS}

The empirical findings of this study revealed that there is a long-run relationship between remittances, financial development, and growth. The outcome of the study also confirms that remittances and financial development have not engendered the growth of the Nigeria economy. It is, therefore, imperative for the Nigerian government, through the Central Bank, to design and implement a policy framework that would enhance financial deepening and the financial system thus making long-term funds available to the productive or real sector at the minimum interest rate. This will culminate into higher productivity and in turn economic growth. Since remittances have not fostered economic growth because a large proportion of them are spent on consumption instead of productive investment, policymakers should setup investment vehicles such as Diaspora bonds among others, to encourage Nigerians working abroad to contribute to national development. Also, the government should stimulate remittances by ensuring that transfers of money by the country's nationals, living and working abroad, is hassle-free.

\section{LIMITATIONS AND FUTURE DIRECTIONS}




\section{Anetor}

The study investigated the relationship between remittances, financial sector development and economic growth in Nigeria. The study established that financial sector development plays a complementarity role in remittances and economic growth nexus. However, the study did not estimate the minimum level of financial development that must be attained before achieving economic growth.

It is, therefore, pertinent for future study to examine the thresholds of financial sector development in the remittances-growth nexus in Nigeria.

\section{REFERENCES}

Abida, Z. \& Sghaier, I. M. (2014). Remittances, financial development and economic growth: the case of North African countries. Romanian Economic Journal, 17(51): 137-169.

Adams, R. H. \& Page J. (2005). Do international migration and remittances reduce poverty in developing countries? World development, 33(10): 1645-1669.

Adarkwa, M. A. (2015). Impact of remittances on economic growth: evidence from selected West African countries (Cameroon, Cape Verde, Nigeria and Senegal). African Human Mobility Review, 1(2): 178-202.

Adenola, F. \& Saibu, O. M. (2017). Does population change matter for long run economic growth in Nigeria? International Journal of Development and Sustainability, 12(6): 1955-1965.

Adenutsi, D.E. (2011). Financial development, international migrant remittances and endogenous growth in Ghana. Studies in Economics and Finance, 28(1): 68-89.

Agbonkhese, A. O. \& Asekome, M. O. (2014). Impact of public expenditure on the growth of Nigerian economy. European Scientific Journal, 10(28): 219-229.

Aggarwal, R., Demirgüç-Kunt, A. \& Peria, M. S. M. (2011). Do remittances promote financial development? Journal of Development Economics, 96(2): 255-264.

Akinpelu, Y. A., Ogunbi, O. J., Bada, O. T. \& Omojola, O. S. (2013). Effects of remittance inflows on economic growth of Nigeria. Developing Country Studies, 3(3): 113-122.

Ambrosetti, E., Cela, E. \& Fokkema, C. M. (2011). The remittances behaviour of the second generation in Europe: altruism or self-interest? Ancona: Università Politecnica delle Marche, Dipartimento di Scienze Economiche e Sociali.

Anetor, F.O. (2016). Capital inflows and exchange rates in Nigeria: a vector autoregressive (VAR) approach. Journal of Global Economics, Management and Business Research 7(4): 246-256.

Anton, K. I. (2010). The impact of nutritional status of children in Ecuador. International Migration Review, 44, $269-299$.

Audu, N. P. (2012). The macroeconomic effect of remittances on the Nigerian economy: a time series approach. International Journal of Academic Research in Accounting, Finance and Management Sciences, 2(3): 142-155.

Bagehot, W. (1873). Lombard Street: A Description of the Money Market. London: John Murray.

Barajas, A., Chami, R., Fullenkamp, C., Gapen, M. \& Montiel, P. (2009). Do workers' remittances promote economic growth? IMF working paper WP/09/153.

Belloumi, M. (2014). The relationship between trade, FDI and economic growth in Tunisia: An application of the autoregressive distributed lag model. Economic Systems, 38(2): 269-287.

Bettin, G. \& Zazzaro, A. (2012). Remittances and financial development: substitutes or complements in economic growth? Bulletin of Economic Research, 64(4): 509-536.

Calderón, C. \& Liu, L. (2003). The direction of causality between financial development and economic growth. Journal of Development Economics, 72(1): 321-334.

Cameron, R. (1967). Banking in the Early Stages of Industrialization. New York: Oxford University Press.

Catrinescu, N., Leon-Ledesma, M., Piracha, M. \& Quillin, B. (2009). Remittances, institutions, and economic growth. World Development, 37(1): 81-92.

Chami, R., Fullenkamp, C., \& Jahjah, S. (2005). Are immigrant remittance flows a source of capital for development? IMF Staff Papers, 52(1): 55-82.

Choe, J. I. (2003). Do foreign direct investment and gross domestic investment promote economic growth? Review of Development Economics, 7(1): 44-57.

Chowdhury, M. (2016). Financial development, remittances and economic growth: evidence using dynamic panel estimation. The Journal of Applied Economic Research, 10(1): 35-54

Danmola, R. A. \& Wakili, A. M. (2013). The impact of net migrant remittance on economic growth: evidence from Nigeria. International Journal of Humanities and Social Science, 3(8): 303-315.

De la Brière, B., De Janvry, A., Lambert, S. \& Sadoulet, E. (1997). Why Do Migrants Remit? An Analysis for the Dominican Sierra. FCND Discussion Paper No. 37

Demetriades, P.O. \& Hussein, K.A. (1996). Does financial development cause economic growth? Time-series evidence from 16 countries. Journal of Development Economics, 51(2): 387-411.

Durand, J., Kandel, W., Parrado, E. A. \& Massey, D. S. (1996). International migration and development in Mexican communities. Demography, 33(2): 249-264.

Durusu-Ciftci, D., Ispir, M.S. \& Yetkiner, H. (2017). Financial development and economic growth: some theory and more 
evidence. Journal of Policy Modeling, 39, 290-306.

Elbadawi, I. A., de Rezende Rocha, R. \& Mundial, B. (1992). Determinants of expatriate workers' remittances in North Africa and Europe (No. 1038). Country Economics Department, World Bank.

Fedorová, D. (2016). Selection of unit root test on the basis of length of the time series and value of AR (1) parameter. STATISTIKA, 96(3): 47-64.

Feeny, S., lamsiraroj, S. \& McGillivray, M. (2014). Remittances and Economic Growth: Larger Impacts in Smaller Countries? The Journal of Development Studies, 50(8): 1055-1066.

Giuliano, P. \& Ruiz-Arranz, M. (2009). Remittances, financial development, and growth. Journal of Development Economics, 90(1): 144-152.

Goldsmith, R.W. (1969). Financial Structure and Development. New Heaven, CT: Yale University Press.

Gregorio, J. \& Guidotti, P.E. (1995). Financial development and economic growth. World Development, 23(3): $433-448$.

Gupta, S., Pattillo C. A., \& Wagh, S. (2009). Effect of remittances on poverty and financial development in sub-Saharan Africa. World development, 37(1): 104-115.

Hoddinott, J. (1994). A model of migration and remittances applied to Western Kenya. Oxford Economic Papers, 46(3): 459476.

Keho, Y. (2017). The impact of trade openness on economic growth: the case of Cote d'Ivoire. Cogent Economics and Finance, 5(1): 1332820.

Kumar, R. R., Stauvermann, P. J., Patel, A. \& Prasad, S. (2018). The effect of remittances on economic growth in Kyrgyzstan and Macedonia: accounting for financial development. International Migration, 56(1): 95-126.

Levine, R. (2005). Finance and growth: Theory and evidence. In Handbook of Economic Growth (Ed.) Philippe Aghion and Steven Durlauf. Amsterdam: North Holland.

Lim, S. \& Simmons, W. O. (2015). Do remittances promote economic growth in the Caribbean community and common market? Journal of Economics and Business, 77, 42-59.

Lucas, R. E. B. \& Stark, O. (1985). Motivations to remit: Evidence from Botswana. Journal of Political Economy, 93(5): 901918.

McKinnon, R.I. (1973). Money and capital in economic development. Brookings Institution, Washington, DC.

Meyer, D. \& Shera, A. (2017). The impact of remittances on economic growth: An econometric model. Economia, 18(2): 147155.

Misati, R. N. \& Nyamongo, E. M. (2011). Financial development and private investment in sub-Saharan Africa. Journal of Economics and Business, 63(2): 139-151.

Mundaca, B. G. (2009). Remittances, financial market development, and economic growth: the case of Latin America and the Caribbean. Review of Development Economics, 13(2): 288-303.

Nyamongo, E. M., Misati, R. N., Kipyegon, L. \& Ndirangu, L. (2012). Remittances, financial development and economic growth in Africa. Journal of Economics and Business, 64(3): 240-260.

Ogbechie, C. \& Anetor, F. O. (2016). Determinants of capital flows into Nigeria: an autoregressive-distributed lag (ARDL) approach. Journal of Economic and Trade, 1(1): 38-50.

Oluwafemi, A. \& Ayandibu, A. O. (2014). Impact of remittances on development in Nigeria: challenges and prospects. Journal of Sociology and Social Anthropology, 5(3): 311-318.

Oshota, S. O. \& Badejo, A. A. (2015). Impact of Remittances on Economic Growth in Nigeria: Further Evidence. Economics Bulletin, 35(1): 247-258.

Osili, U. (2004). Migrant and housing investment: Theory and evidence from Nigeria. Economic Development and Cultural Change, 52, 821-850.

Pradhan, G., Upadhyay, M. \& Upadhyaya, K. (2008). Remittances and economic growth in developing countries. The European Journal of Development Research, 20(3): 497-506.

Raheem, I. D. (2015). Remittances, financial sector development and efficiency and growth in Africa. Indian Journal of Finance, 9(2): 25-34.

Rao, B. B. \& Hassan, G. M. (2011). A panel data analysis of the growth effects of remittances. Economic Modelling, 28, 701709.

Ratha, D., De, S., Plaza, S., Schuettler, K., Shaw, W., Wyss, H. \& Yi, S. (2016). Migration and remittances: Recent developments and outlook. Migration and Development Brief, 26, 4-6.

Sibindi, A. B. (2014). Remittances, financial development and economic growth: empirical evidence from Lesotho. Journal of Governance and Regulation, 3(4): 116-124

Schrieder, G. \& Knerr, B. (2000). Labour migration as a social security mechanism for smallholder households in Sub-Saharan Africa: The case of Cameroon. Oxford Development Studies, 28(2): 223-236.

Schumpeter, J.A. (1912). The theory of economic development: An inquiry into profits, capital, credit, interest, and business cycle. Cambridge, MA: Harvard University Press.

Shaw, E.S. (1973). Financial Deepening in Economic Development. New York, NY: Oxford University Press.

Stark, O. (1991). Migration in LDC's: Risk, remittances, and the family. Finance and Development, 28(4): 41-44.

Švigir, M. \& Milo š, J. (2017). Relationship between inflation and economic growth; comparative experience of Italy and Austria. FIP-Financije i pravo, 5(2): 91-101.

Jawaid, S.T. \& Raza, S. A. (2012). Workers' remittances and economic growth in china and Korea: an empirical analysis. Journal of Chinese Economic and Foreign Trade Studies, 5(3): 185-193.

Valickova, P., Havranek, T. \& Horvath, R. (2015). Financial development and economic growth: a meta-analysis. Journal of Economic Surveys, 29(3): 506-526.

Woodruff, C. (2007). Mexican microenterprise investment and employment: The role of remittances. Integration and Trade, 


\section{Anetor}

11(27): 185-209.

Woodruff, C. \& Zenteno R. (2007). Migration networks and microenterprises in Mexico. Journal of Development Economics, 82(2): 509-528.

Yang, D. (2008). International migration, remittances and household investment: Evidence from Philippine migrants' exchange rate shocks. The Economic Journal, 118(528): 591-630. 
Appendix-I

\begin{tabular}{ccccccccc}
\hline & GRGDP & $\boldsymbol{R E M}$ & $\boldsymbol{F D V}$ & $\boldsymbol{I N F}$ & $\boldsymbol{T O P}$ & $\boldsymbol{P O P}$ & $\boldsymbol{G X P}$ & $\boldsymbol{G C F}$ \\
\hline Mean & 4.45 & 3.32 & 14.47 & 19.56 & 14.91 & 2.57 & 3.32 & 12.05 \\
Median & 5.30 & 2.58 & 12.65 & 12.21 & 9.57 & 2.57 & 2.95 & 11.74 \\
Maximum & 14.60 & 13.04 & 24.34 & 72.83 & 45.61 & 2.67 & 8.20 & 29.73 \\
Minimum & -7.57 & 0.01 & 9.15 & 5.38 & 0.09 & 2.48 & 0.06 & 5.46 \\
Std. Dev. & 4.46 & 3.71 & 4.50 & 17.94 & 14.71 & 0.06 & 2.97 & 4.88 \\
Observations & 35 & 35 & 35 & 35 & 35 & 35 & 35 & 35 \\
\hline Source: Authors' Computation &
\end{tabular}

Source: Authors' Computation using EViews 9

Table 1. Summary Statistics of Variables 


\begin{tabular}{ccccccc}
\hline Variable & $\begin{array}{c}\text { Augmented } \\
\text { Dickey- } \\
\text { Fuller }\end{array}$ & With & $\begin{array}{c}\text { Order of } \\
\text { Integration }\end{array}$ & $\begin{array}{c}\text { Philips- } \\
\text { Perron }\end{array}$ & $\begin{array}{c}\text { Order of } \\
\text { Integration }\end{array}$ \\
\hline & $\begin{array}{c}\text { With } \\
\text { Constant }\end{array}$ & & With & With Trend \\
and Constant & Constant & $-3.19^{* *}$ & -3.10 & $\mathrm{I}(0)$ \\
$G R G D P$ & $-3.34^{* *}$ & -3.26 & $\mathrm{I}(0)$ & $-6.64^{* * *}$ & $-6.53^{* * *}$ & $\mathrm{I}(1)$ \\
$R E M$ & $-6.31^{* * *}$ & $-6.22^{* * *}$ & $\mathrm{I}(1)$ & $-5.59^{* * *}$ & $-5.50^{* * *}$ & $\mathrm{I}(1)$ \\
$F D V$ & $-5.60^{* * *}$ & $-5.52^{* * *}$ & $\mathrm{I}(1)$ & $-6.75^{* * *}$ & $-6.65^{* * *}$ & $\mathrm{I}(1)$ \\
$R e m F d v$ & $-6.72^{* * *}$ & $-6.62^{* * *}$ & $\mathrm{I}(1)$ & $-9.06^{* * *}$ & $-9.62^{* * *}$ & $\mathrm{I}(1)$ \\
$I N F$ & -2.81 & $-3.83^{* *}$ & $\mathrm{I}(0)$ & $-5.46^{* * *}$ & $-5.37^{* * *}$ & $\mathrm{I}(1)$ \\
$T O P$ & $-5.46^{* * *}$ & $-5.37^{* * *}$ & $\mathrm{I}(1)$ & $-4.37^{* * *}$ & $-3.99^{* *}$ & $\mathrm{I}(1)$ \\
$P O P$ & $-4.44^{* * *}$ & $-4.10^{* *}$ & $\mathrm{I}(0)$ & $-5.16^{* * *}$ & $-5.06^{* * *}$ & $\mathrm{I}(1)$ \\
$G X P$ & $-5.30^{* * *}$ & $-5.64^{* * *}$ & $\mathrm{I}(1)$ & $-4.27^{* * *}$ & $-3.89^{* *}$ & $\mathrm{I}(0)$ \\
\hline$G C F$ & $-4.46^{* * *}$ & $-3.73^{* *}$ & $\mathrm{I}(0)$ & & &
\end{tabular}

Source: Authors' Computation using EViews 9

Note: $* * *, * * *$ represent $1 \%, 5 \%$, and $10 \%$ significance level respectively

Table 2. Unit Root Tests 
International Journal of Management, Economics and Social Sciences

Appendix-III

\begin{tabular}{ccccc}
\hline Variable & Coefficient & Std. Error & t-Statistic & Prob. \\
\hline$C$ & 26.34 & 33.57 & 0.78 & 0.44 \\
$R E M$ & -4655.38 & 1379.73 & -3.37 & 0.002 \\
$F D V$ & -4633.07 & 1376.99 & -3.36 & 0.003 \\
$R e m F d v$ & 4654.89 & 1379.69 & 3.37 & 0.002 \\
$I N F$ & -2.34 & 1.07 & -2.18 & 0.04 \\
$T O P$ & 1.64 & 2.18 & 0.75 & 0.45 \\
$P O P$ & -44.56 & 47.98 & -0.92 & 0.36 \\
$G X P$ & -4.68 & 3.34 & -1.39 & 0.17 \\
$G C F$ & -12.71 & 5.18 & -2.45 & 0.02 \\
\hline
\end{tabular}

Source: Authors' Computation using EViews 9

Dependent Variable $\triangle G R G D P$

Table 4. ARDL Estimated Long-run Coefficient 


\begin{tabular}{ccccc}
\hline Variable & Coefficient & Std. Error & $\boldsymbol{t}$-Statistic & Prob. \\
\hline$\triangle R E M$ & -3475.36 & 810.69 & -4.28 & 0.00 \\
$\triangle F D V$ & -3479.81 & 810.84 & -4.29 & 0.00 \\
AREMFDV & 3475.00 & 810.69 & 4.28 & 0.00 \\
$\triangle I N F$ & -1.75 & 0.74 & -2.36 & 0.02 \\
$\Delta T O P$ & 1.22 & 1.61 & 0.76 & 0.45 \\
$\triangle P O P$ & 159.04 & 99.04 & 1.60 & 0.12 \\
$\triangle G X P$ & -3.49 & 2.37 & -1.47 & 0.15 \\
$\triangle G C F$ & -1.78 & 3.16 & -0.56 & 0.57 \\
ECT(-1) & -0.74 & 0.12 & -6.15 & 0.00 \\
R-squared & 0.84 & & & \\
F-statistic & 9.48 & & & 0.000006 \\
DW-statistic & 1.95 & & & \\
\hline Source: Authors' Computation using EViews 9 & & &
\end{tabular}

Source: Authors' Computation using EViews 9

Dependent Variable $\triangle G R G D P$

Table 5. Short-run Estimate Using the ARDL Approach 